\title{
A different appetite for sovereignty? Independence movements in subnational island jurisdictions
}

Godfrey Baldacchino ${ }^{\mathrm{a} *}$ and Eve Hepburn ${ }^{\mathrm{b}}$

${ }^{a}$ Island Studies Programme, University of Prince Edward Island, 550 University Avenue, Charlottetown, Prince Edward Island, Canada C1A 4P3; ${ }^{b}$ School of Social and Political Science, University of Edinburgh, 21 George Square, Edinburgh EH8 9LD, UK

Local autonomy in a subnational jurisdiction is more likely to be gained, secured or enhanced where there are palpable movements or political parties agitating for independence in these smaller territories. A closer look at the fortunes, operations and dynamics of independence parties from subnational island jurisdictions can offer some interesting insights on the appetite for sovereignty and independence, but also the lack thereof, in the twenty-first century.

Keywords: independence; islands; self-determination; sovereignty subnational jurisdictions; stateless nationalist and regionalist parties

\section{Introduction: the iron law of independence?}

History was in the making when the Republic of South Sudan became an independent state on 9 July 2011, was welcomed as the 193rd member of the United Nations (UN) on 14 July, and joined the Africa Union on 28 July. This new country has strong claims to its current status; long struggles to maintain independence from encroaching European powers in the nineteenth century; run for some time as a separate region within the colony of Egypt; fighting two civil wars since the independence of Sudan in 1956; bearing considerable neglect from the central Sudanese government; and approving, by a whopping 98 per cent majority, the decision to secede as a separate state in a January 2011 referendum (voter turnout: 97 per cent). Substantial oil deposits provide considerable economic potential to this nascent sovereign state.

\footnotetext{
*Corresponding author. Email: gbaldacchino@upei.ca
} 
South Sudan is the latest country to emerge from the wave of decolonisation. Aspirations for autonomy, the removal of long years of oppression, laced with increasingly acceptable overtures to national identity, provided successful recipes for the transitioning to full independence, with the blessing of the international community. Former powers - as in the case of Sudan with regards to South Sudan - may resist this transition (possibly by the use of violence and military action), and they can flex whatever international clout they might possess in order to sway significant players in the region not to support aspirations for independence. For instance Palestine's bid to be recognised as a sovereign state at and by the UN in 2011 is moot. If all else fails, countries may still decide not to recognise jurisdictions even if they should declare themselves independent: at the time of writing, the sovereign state of Kosovo has been recognised by 83 other sovereign states.

But such an observation suggests that all potential countries would become independent if they could. This is not the case.

Contrast the South Sudan referendum with another event that took place, also in Africa, a few months before. On 31 March 2011, the island of Mayotte, in the Indian Ocean, became France's 101st department and its 5th overseas department. Mayotte is also likely to become an Overseas Region of the European Union (EU) in 2014. Mayotte voted not to join its three neighbouring islands to independence in 1975 (as the Republic of the Comoros), a move interpreted by France to maintain its tutelage over the island. On 29 March 2009, in the referendum to decide whether or not Mayotte should become a French department, 95.2 per cent of Mahorais voters were in favour (voter turnout: 61 per cent) (Larned, 2011).

The case of Mayotte reminds us of another category of (largely small and self-governing) jurisdictions that may not wish to assume the mantle of full sovereignty. Indeed, there has been a sharp decline in the pursuit of sovereignty by sub-state regions and stateless nations that form part of larger multi-level states. The aims of subnational territorial movements, spearheaded by stateless nationalist and regionalist parties (SNRPs), tend to reflect a desire to embark on innovative autonomy arrangements that fall short of full sovereignty. But why choose something other than statehood?

\section{Historical unfolding}

Starting with Ethiopia in 1941, no less than 129 countries have achieved independence in the last 70 years. This massive wave of decolonisation has been spearheaded by former colonies pressing for, and achieving, full sovereignty, as well as by the breakup of morally bankrupt empires (Soviet Union, Yugoslavia) in the face of agitations for self-determination by peoples who saw themselves as dispossessed, stateless nations. There remains today no shortage of 
potential candidates for independence: the UN Special Committee on Decolonisation (the Committee of 24) still monitors 16, 'non-self governing territories' (all but two being islands). There are hundreds of stateless regions and nations clamouring recognition, increased autonomy, and/or outright full sovereignty. And yet, certainly amongst the smallest of these and various other (mainly island or archipelagic) territories, there is perhaps not much appetite for independence. Instead, most of these jurisdictions have decided that they would rather retain some aspects of autonomy while maintaining or seeking better terms of integration with their metropolitan/colonial power.

Many subnational regions and stateless nations are not interested in secession, and would have confirmed this in various independence referenda. Indeed, in a practice that can be dated back certainly as far as $1204 \mathrm{CE}$ (in the case of the Channel Islands), various sub-national jurisdictions have secured or stuck to their autonomy status, and in some cases enhanced it. These include Denmark's Faroe Islands and Greenland, France's Mayotte, China's Hong Kong and Macau, and New Zealand's Cook Islands: they have benefitted from measures of self-government - often not shared by other component units of the polity - while remaining comfortably lodged within the purview of a larger, richer, metropolitan state. Indeed, there has been a growing acceptance on the part of states that multiple tiers of government can lead to better policy making (thereby precipitating plans for the decentralisation or devolution of powers to subnational jurisdictions); whilst on the part of the subnational jurisdictions themselves, the benefits of maintaining a form of association with a larger state (be it 'free association' or 'sovereignty-association') often outweigh the risks associated with complete separation.

The advantages of affiliation, and the perils of independence - depending, of course, on one's point of view - are starkly evident in the following cases from recent decades, all drawn from the UK's Overseas Territories: catastrophic volcanic eruptions (Montserrat, Tristan da Cunha); the financing of expensive infrastructure projects, such as an international airport (St Helena); political corruption (Turks and Caicos); a banking scandal (Montserrat); the provision of security in the face of an invasion by another state (Falklands); and the rule of law in the face of rampant child abuse (Pitcairn).

\section{Tweaking a relationship}

One key distinction between locales agitating for full independence and those stubbornly resisting it concerns the nature of the 'small peripheral territory versus metropolis' relationship. An identifiable region that lacks jurisdictional capacity, struggling against deliberate or perceived discrimination and repression from a larger rapacious state, feeling itself to be a disempowered or abused minority on economic, linguistic, cultural or ethnic grounds, and 
solidifying its identity claims with a suitable history and ontology, is more likely to breed overt and covert political resistance. This situation could spawn movements that could consider and present secession and independence as desirable political options, and fan popular sentiment in their favour. Secessionist parties in such territories would encourage the adoption of such a narrative. But what is seen as a benign patron state, perhaps keen to maintain the smaller unit within its purview, would be disposed to support its wards with welfare, employment, security, investment and other benefits, perhaps even citizenship, proving to one and all that their union pays dividends; that theirs is not a colonial, imperial or unequal relationship. These are classic strategies of 'territorial management', whereby states seek to accommodate the interests and demands of subnational regions in order to ward off the threat of secession and strengthen the unity of the state (Keating, 1988). Indeed, if territorial management strategies for different subnational regions are unequal or asymmetric, it is usually to the advantage of the smaller unit.

Elites, and the general public, in many small territories have mobilised in support of such an evolving relationship with a former colonial power; preferring this to the alternative of independence. The latter could, in practice, lock in a status of being alone, poor and destitute in a harsh and unforgiving world. But it could also mean locking into an unhappy, political subservience with a different, larger, closer power. So little Anguilla in 1968 seceded from St Kitts-Nevis-Anguilla, preferring to remain a colony of London than a colony of Basseterre. Mayotte has emphatically preferred Paris to Moroni, the capital of neighbouring Comoros. The Dutch Antilles also broke up because its constituent parts would rather be directly subordinate to distant Amsterdam than to neighbouring Willemstad, in Curaçao. In these and similar cases, the metropolitan power may be complicit in facilitating this move: historically, of the former colonial powers, France has probably been keenest to maintain its empire, and co-opt its wards via assimilation (Guadeloupe, Martinique, French Guiana and Réunion from as early as 1946). With its numerous overseas departments and territories (and mainly islands) scattered all over the planet, France possesses the second-largest Exclusive Economic Zone in the world, covering 11,035,000 $\mathrm{km}^{2}$, only just behind the USA (with 11,351,000 km²).

Of course, in the struggle for loyalty and legitimacy, a state sympathetic to the smaller territory's continued integration and perseverance within the status quo would look nervously at any movements agitating for secession; so also would the politico-economic elites of the smaller unit (unless they themselves were pro-independence). The existence of, and extent of popular support for SNRPs within the smaller territory can indeed act as a barometer of overall satisfaction, or disappointment, with the territory-metropole relationship. With this in mind, SNRPs may not necessarily have full sovereignty in their sights, or only perhaps as a long-term goal. Tweaking the relationship with 
the metropole in their favour may be a more immediate, and more reachable, policy objective.

This observation is becoming increasingly accepted in the literature on SNRPs. Rather than pursue outright independence, many SNRPs prefer forms of enhanced autonomy within the state (Türsan, 1998; Elias, 2008). However, constitutional restructuring is not the only goal of these movements. Such parties seek the general aim of 'territorial empowerment', which includes seeking to enhance the political, socioeconomic and cultural capacity of the region, often within the framework of the state (Hepburn, 2009). The presence and activities of independence-leaning movements can contribute significantly to a more successful negotiation with, and securing of even more generous measures of autonomy and capacity from, metropolitan powers. This is especially true when SNRPs can exploit the existence of a distinct history, culture, language and identity to form the basis of their nationalist discourse and claims for selfdetermination (Keating, 1988; Elias, 2008; Hepburn, 2009). This mobilisation can also be facilitated by the existence of autonomy arrangements which enable the territory to flex its capacity, and potential for even more self-government, as a political entity. In some cases, territories are bracing for eventual independence referenda (Bougainville, New Caledonia, Scotland) or may entertain fresh referenda for the same purpose (Tokelau, Nevis).

Greenland/Kalaallit Nunaat has held a non-binding referendum on enhanced autonomy in November 2008, which was passed with a 75 per cent approval (turnout: 72 per cent). Its proposals - which the Danish Parliament has promised to honour - are to expand home rule in 30 areas; give Greenland a say in foreign policy and a more definite split of future oil revenue; make Greenlandic the sole official language; phase out Greenland's generous subsidies from Copenhagen; and recognise Greenlanders as a separate people under international law. Like Greenland, the Faroe Islands, are also working through a 'step by step' process that could lead to independence, aided by the presence of SNRPs in regional governments. But the situation is different in another Scandinavian territory. The Åland Islands complain that Helsinki remains indifferent or even hostile to requests for greater autonomy: there is no likelihood for an enhanced autonomy referendum there. Does the small, independence-leaning, political party in Åland justify Helsinki’s stance? Maria Ackrén and Bjarne Lindström explain the different dynamics behind these three Scandinavian independence movements in their contribution to this collection.

\section{Who needs independence?}

Strong arguments - cultural, fiscal, economic and political - in favour of independence remain. Many can arise out of sheer frustration with existing 
autonomy arrangements. Should these be interpreted by the public, or its elites, as similar to the oppression that characterised many colonial relationships, then agitation for independence can be expected. And yet, the drive for independence à la vingtième siècle has practically ground to a snail's pace; and this is worthy of some reflection.

First, such an 'infinite pause' is partly due to the changing nature of states in a post-Westphalian system. On one hand, the international system grants considerable powers and legitimacy to existing states, themselves embroiled in an intricate web of bilateral and multilateral treaties. With few exceptions, like Antarctica or Svalbard, 'three-dimensional national cages' (Palan, 2003: 97) of contiguous territorial states dominate the system. Any aspiring new state today would not only need to be hived off from an existing state that would be expected to feverishly oppose its recognition by other states in the system (Serbia with regard to Kosovo being a recent example); it would also have to contend with the general challenge of 'extantism' (the status quo of states). In another sense, though, the nature of statehood is itself changing, whereby states have lost their capacity for being the only important units for political decision-making. State sovereignty is being eroded from below by decentralisation, and from above by globalisation and supranational integration. This has made statehood a less attractive goal for some subnational actors, who have sought to exploit the political spaces beneath, above and between states to advance their political projects.

Second, new opportunities for subnational mobilisation have been created within the context of deepening supranational integration. This is most obvious in Europe. European networks, lobbying organisations and institutions have been set up to strengthen the rights and recognition of sub-state institutions, such as establishment of the EU Committee of the Regions in 1994. This new institutional space adds further incentive to regions to organise themselves and agitate as such, often meaning to circumvent their national governments (e.g. Keating, 2005). Yet involvement in a 'Europe of the Regions' is not the only option available to subnational movements; the security afforded by EU membership may also make the drive for full sovereignty more appealing as evidenced by the 'independence in Europe' platform of the Scottish National Party (SNP).

There are numerous SNRPs, also described as 'ethno-regionalist parties' (Türsan, 1998; Miodownik \& Cartrite, 2006), in Europe today that command significant public support, and even participate in national governing coalitions. Many have moved from fringe/niche/pariah status to mainstream political players, with all the challenges that this shift from 'protest to power' entails (Hepburn, 2009). Perhaps counter-intuitively, the drive for wholesale independence may have been dampened by this shift to the mainstream. The co-optation of such parties into national politics, and the granting 
of some of their requests for devolution, may have been part of a 'territorial management' strategy by metropolitan powers to detract support for secession (Of course, this strategy could backfire, as appears to be the case with Scotland and the recent rise in popularity of the SNP, though not necessarily a rise in support for independence).

Indeed, demands for independence have become more and more uncommon amongst the SNRPs of Europe. Rather than clamour for full sovereignty, the majority of SNRPs have, over time, opted for creative forms of shared sovereignty within an integrationist Europe (Hepburn, 2010). This is reflected in the composition and autonomy claims of the European Free Alliance, the premier alliance of SNRPs in the EU. Most members seek to renegotiate their autonomy within a 'Europe of the Peoples and Nations', rather than demand separate membership of a 'Europe of States' (Hooghe, 1996; Loughlin, 1996; Jeffery, 2002; Keating, 2005; Elias, 2008; Hepburn, 2010). This accommodation strategy is also seen in the realpolitik of fringe independentist parties - as currently exist in the Balearic Islands (Catalonia/Spain), Corsica (France) and Sardinia (Italy). In his contribution to this collection, André Fazi meticulously charts how independence-leaning parties in these three sub-national island jurisdictions (SNIJs) can still impact on public policy, especially by increasing the polarisation and fragmentation amongst nationalist parties of various dispositions.

Third, and somewhat ironically, at a time when the international relations climate is increasingly safe to states qua states, irrespective of size (e.g. Bartmann, 1992), there are clear economic and security advantages in being associated with a larger, richer, metropolitan patron. Throughout the twentieth century, only three states have been assimilated with/by neighbours, and thus disappeared: South Yemen (into Yemen), Zanzibar (merged with Tanganyika to form Tanzania) and Somaliland (in Somalia - though, to be fair, we may yet see a resurgence of the successor to the former British protectorate). Thus, once an entity is a recognised (even if subnational or neo/post-colonial) jurisdiction, the security bestowed by the very act of statehood is a tantalising prospect. What today are referred to as 'failed states' would easily have been, in the past, ripe for invasion and assimilation by covetous neighbouring powers; this is not so much the case nowadays.

And yet, security can mean different things to different people: falling under the aegis of a larger, more powerful state, while maintaining strong levels of domestic autonomy, has its own advantages. Perhaps, even an envious situation of 'having the cake and eating it too' (Palan, 1998): all (or most) of the ceremonial, symbolic, regulatory and operational trappings of sovereignty, plus a much stronger ally in the corner for those delicate occasions that warrant a display of force or influence, a source of economic largesse, a pool of potential tourists, a custodian of a lucrative and diverse labour market, an appealing location for pursuing higher education, and purveyor of prized citizenship rights. The evidence 
is telling: globally, the citizens of SNIJs have a per-capita income almost three times higher than those in small island developing states (SIDS) (McElroy \& Sandborn, 2005). In their contribution to this collection, Jerome L. McElroy and Courtney E. Parry systematically outline how SNIJs have consistently 'done' better in relation to comparable 'SIDS' on a broad range of demographic, epidemiological, social and economic indicators over recent decades. The question is thus posed: is it worth being sovereign? Tellingly, various peoples are agitating for 'home unions' that would allow them increased local autonomy but without rescinding their current incorporation within an existing sovereign state. As Sir John Swan, former Premier of Bermuda - since 1999 the largest (by population) of the UK's 14 Overseas Territories - famously put it in 1982: 'With the Americans to feed us and the British to defend us, who needs independence?' (cited in Connell, 1994).

The Caribbean is a case in point, as reviewed by Peter Clegg in his contribution to this collection: between 1967 and 2007, various referenda have been held: in Bermuda, US Virgin Islands, Puerto Rico (three times), Bonaire, Sint Maartin, Saba, Curaçao, St Eustatius ... none have endorsed sovereignty. We have noted how tiny Anguilla actually seceded from St Kitts-Nevis-Anguilla and preferred to remain a colony of Britain. Antigua and Barbuda and St Kitts-Nevis were the last to join the list of sovereign states in the region, securing independence in 1981 and 1983 respectively. Why have none 'graduated' since? Do the names of both these countries betray an uncomfortable and fickle union, liable to fission? Do subnational island autonomies, like Nevis and Tobago, with their independence movements and distinct ethno-territorial identities, perceive that they may be better off as dependencies of other states rather than sovereign units?

\section{A different kind of sovereignty}

Given this background, we propose that the dynamics for any moves for political independence in the twenty-first century may be different from those of the twentieth. True, there will still be peoples whose main goal will be to rid themselves of what they experience as illegitimate oppression: dare we suggest Aceh, Chechnya, Irian Jaya and Kurdistan? The fission of former empires may yet continue. But, the aspirations of subnational regions and colonies to independence is grinding to a halt, and in the rare cases that they still exist, such aspirations for independence are increasingly driven by hardnosed, strategic and pragmatic economic arguments. Meanwhile, both creative governance and fiscal vicissitudes have already ushered in examples of 'sovereign states' that approximate suzerain entities. Note Palau, the Marshall Islands and the Federated States of Micronesia: the three 'Compact' States in the Pacific, 'hybrid jurisdictions' (Levine \& Roberts, 2005) that have relinquished their 
international relations to the USA; or three other Pacific countries - Kiribati, Nauru and Papua New Guinea - becoming 'offshore processing centres' for those seeking asylum status in Australia. Political parties, sensitive to voters' wishes and concerns, may be keen to achieve a different kind of sovereignty, one that secures enhanced local autonomy (and especially in certain sensitive areas of policy); but ultimately maintains a special relationship with a benevolent patron. This is the case for Puerto Rico with the USA; Aruba with the Netherlands; Mayotte with France; Turks and Caicos with the UK, Hong Kong with China, and Greenland/ Kalaallit Nunaat with Denmark.

Referring to 'a different kind of sovereignty' invariably brings to mind 'sovereignty association', a 'modified' version of independence conceived in the late 1960s by the Mouvement Souveraineté-Association (MSA) set up by René Lévesque to reform relations between Quebec and the rest of Canada. The MSA succeeded in uniting the sovereigntist-leaning political forces in Quebec as the Parti Québécois (PQ), which won the provincial elections in 1976, and triggered two nail-biting provincial referenda (in 1980 and 1995) about the future of Quebec-Canada relations. The appeal for a secessionistleaning political agenda in Quebec appears to have been revived of late, with the election of a (albeit minority) PQ Government in 2012; but, meanwhile, the province appears to have waned of late, it is clear that Quebec has greatly expanded its provincial jurisdictional reach, while persisting as a recognised 'nation within a united Canada' (CBC News, 2006). The province has a near monopoly of competence in policy fields like culture, health, language, immigration and education (e.g. Gagnon, 2009). How was this accomplished? Not by a dramatic referendum, but incrementally, à la piece.

Another example of 'a different kind of sovereignty' is that of the Cook Islands. Like Niue, the Cooks are a self-governing state in free association with New Zealand, and a full member of the 16-member Pacific Islands Forum. The Cook Islands Government enjoys full executive powers; it has established separate diplomatic relations with over 20 states at the embassy or high commission level; and 23 states (including Australia, New Zealand and the USA, as well as the EU) maintain full diplomatic relations accredited to the Cook Islands. Cook Islanders retain New Zealand citizenship: herewith a state that does not confer citizenship. The Cooks are not members of the UN; yet, their citizens can 'enjoy all the prerogatives of sovereignty with the most permissive and generous arrangements for international relations available to any dependent territory in the world' (Bartmann, 2008: 72).

\section{Island cases}

The reference to the Cooks alerts us to another particularity of this volume: we are only dealing here with independence movements on islands. It is well 
known that islands can inform us about such dynamics as decolonisation, postcolonialism, globalisation, para-diplomacy and other variations around the sovereignty theme generally. Their pedigree as 'enclave meta-geographies' (Sidaway, 2007), evocative platforms to various disciplinary concerns and pursuits - whether it is evolutionary biology, social anthropology or, more recently, green energy and climate change - is widely acknowledged. Secondly, islands represent quintessential platforms for nation-states, since as delineated spaces, discrete bounded territories that are at once knowable and, because of their consolidated form, readily defensible, they function as ideal embodiments of the state's relationship to the nation (Peckham, 2003: 503). The finite island geography aids the nurturing of a sense of identity that is contiguous with territory (Srebrnik, 2004; Anckar, 2005; Baldacchino, 2005); perhaps one strong explanation for the existence of only a dozen or so inhabited islands in the world divided between more than one country (Royle, 2001: 150-152; Baldacchino, 2013). Thirdly, islands and archipelagos also constitute by far the largest number of small states, as well as of colonial remnants: the CIA World Factbook lists 267 'countries, dependent areas, and other entities', of which about one-third (85) are islands or archipelagos (CIA, 2011). 'Below a population size of 5 million, there is a striking correlation between diminishing size and the salience of island entities' (Bertram \& Poirine, 2007: 327).

Specifically within Europe, islands are not overly well-represented at the top table of the EU: the Council of Ministers. Although the EU does have some small island state members - Cyprus, Malta, and a larger, part-island, Republic of Ireland, with Iceland recently constituting a candidate member Europe has not witnessed the establishment of an independent island state for some time. And yet, the number of ultra-peripheral regions of the EU has increased: all of these, but one (French Guyana), are islands. Does this mean that the era of island independence has, for the time being, passed in Europe, while island autonomy is all the rage? The SNRPs operating in Europe's numerous SNIJs (Baldacchino, 2006) - such as Åland, Azores, the Canaries, Corsica, Sardinia and Sicily - may be seeking something other than independence. If so, the dynamics behind this behaviour call for a better understanding, especially in comparing this phenomena with 'mainland' territories.

\section{Continental contrasts}

Indeed, the European theatre is insightful for one other set of examples: the small continental microstates. Four small continental European jurisdictions have lingered for centuries as autonomous entities with clear ties to larger states; all are now members of the UN (with a fifth, the Holy See, as a permanent observer). None are members of the EU; four of these five use the euro as their currency. (The exception is Liechtenstein, which has been using the Swiss Franc since 
1920.) The sovereignty of Andorra, Liechtenstein, Monaco and San Marino, and their unfolding on the world stage - with larger Luxembourg as a role model suggests that size is no longer an obstacle to sovereignty. And independence does pay dividends; but possibly only so when its opportunities - for visibility, for participation in international initiatives, for representation - can be adequately and consistently financed. Location, in this case, also helps to facilitate mobility and defray travel costs. As Barry Bartmann convincingly argues in his contribution to this collection, the world's 10 smallest island states (each with populations of 100,000 or less) profess a much more subdued role and constricted reach as independent states than any of their smaller but much richer European continental counterparts. The largest of these 10 by population, Kiribati, lacks a permanent representative at the UN HQ in New York. Its very existence as a territorial state is threatened by sea level rise.

In his contribution to this collection, Stephen Levine confirms that, in the Pacific, 'uncompetitive economic prospects and performance often mock the trappings of sovereignty, self-rule and independence'. In this context, Levine echoes Bartmann (see above), suggesting that the 'free association' that the Cook Islands secured with New Zealand is a smart compromise. Like Niue, the Cooks cannot achieve full sovereignty when the financial assistance provided by New Zealand is required for its government to meet its budgetary needs. Nor may it wish to. Cook Islanders do not have their own separate citizenship; but then, is the absence of UN membership a high price to pay in exchange for what Levine calls 'semi-sovereignty', and which comes along with a permanent life-line to Wellington, where most Cook Islanders are already domiciled? Of the last island territories to achieve independence in the Pacific, only East Timor can be said to match the classic twentieth century mould: like South Sudan, it has escaped from the clutches of what has been widely perceived as an oppressive regime. The other three are the 'Compact States' of Palau, the Marshall Islands and the Federated States of Micronesia. While recognised as independent (including UN membership), they are in 'free association' with their former, and most recent, protector: the USA. What this means is that the USA provides financial assistance over renewable periods, in exchange for the right to operate its armed forces in Compact areas, to demand land for operating bases (subject to negotiation), and to exclude the militaries of other nations other than with its permission.

Like the USA, France still behaves as an imperial power: it maintains territories in every part of the world. Integration into the centralised French 'nation state' has however not always been met (as in Mayotte) by acquiescent and grateful subjects in its various far-flung départements and collectivités d'outre mer. This is especially so in the French Pacific: as Nathalie Mrgudovic outlines in her contribution to this collection, the independence struggles in New Caledonia have been violent, and an independence referendum is 
planned there; while there is a strong independence movement on French Polynesia. And yet, in both jurisdictions, considering sovereignty 'in freeassociation' with France now appears to be a perfectly conceivable option.

\section{Epilogue: what's next?}

Securing independence may be the culmination of a political project; and the beginning of a new state. But it does not necessarily have to stop there. Jurisdictions are works in progress. A domino effect may be set off, with smaller and smaller entities going their own way from what had earlier appeared to be a stable state or viable federal arrangement: thus was the unravelling of the West Indies Federation. And yet, the candidates for such a spectacular fission need not be confined to imperial remnants: the very heart of empire may be also affected. The British Isles include a diverse set of 'countries', counties, islands and archipelagos that enjoy different degrees of autonomy: from the offshore finance driven 'crown colonies' of the Channel Islands; to the oil-rich municipality of Shetland. Should the SNP, in power in Scotland at the time of writing, hold and 'win' its promised independence referendum, would this catalyse political fission across the UK? The real prospects of an independent Scotland could, for example, easily affect the status and political aspirations of Shetland, Orkney and the Western Isles (would they rather be wards of London than of Edinburgh?) as well as the Isle of Man, Jersey, Guernsey, Wales and Northern Ireland. Yet, the most likely outcome of the SNP's proposed referendum on independence is the option of 'independence-lite' or 'devolution max' which mimics the sovereignty-association model. A vote in favour of this option, argues the SNP, would also be seen as a victory for the party as it constitutes a further step towards the unravelling of the UK along post-sovereignty lines. As documented in the contribution by Britt Cartrite to this collection, it appears that it is high time to start conceiving of an alternative to the current 'United Kingdom'.

\section{References}

Anckar, D. (2005) Decentralisation in microstates: where, how and why? Canadian Review of Studies in Nationalism, 32(1-2), pp. 109-120.

Baldacchino, G. (2005) The contribution of social capital to economic growth: lessons from island jurisdictions, The Round Table: Commonwealth Journal of International Affairs, 94(378), pp. 35-50.

Baldacchino, G. (2006) Innovative development strategies from non-sovereign island jurisdictions: a global review of economic policy and governance practices, World Development, 34(5), pp. 852-867.

Baldacchino, G. (2013) A Political Economy of Divided Islands: Unified Geographies, Splitting Polities (Basingstoke: Palgrave Macmillan). 
Bartmann, B. (1992) Lilliput Revisited: Small States in a Changing World. Monograph (Charlottetown, Canada: Institute of Island Studies, University of Prince Edward Island). Available at http://www.upei.ca/iis/art_bb_2 (accessed 5 October 2012).

Bartmann, B. (2008) In or out: sub-national island jurisdictions and the antechamber of para-diplomacy, in: G. Baldacchino \& D. Milne (Eds) The Case for Non-sovereignty: Lessons from Sub-national Island Jurisdictions, pp. 57-75 (London: Routledge).

Bertram, G. \& Poirine, B. (2007) Island political economy, in: G. Baldacchino (Ed.) A World of Islands: An Island Studies Reader, pp. 323-378 (Charlottetown, Canada: Institute of Island Studies, University of Prince Edward Island Luqa Malta Agenda Academic).

CBC News. (2006) House passes motion recognizing Québécois as nation, November 27. Available at http://www.cbc.ca/news/canada/story/2006/11/27/nation-vote. html (accessed 28 August 2011).

CIA. (2011) World Factbook (Washington, DC: Central Intelligence Agency). Available at https:/www.cia.gov/library/publications/the-world-factbook/ (accessed 28 August 2011).

Connell, J. (1994) Britain's Caribbean colonies: the end of the era of decolonisation?, Journal of Commonwealth \& Comparative Politics, 32(1), pp. 87-106.

Elias, A. (2008) Minority Nationalist Parties and European Integration: A Comparative Study (London: Routledge).

Gagnon, L. (2009) Quebec's slow road to sovereignty, The Globe and Mail, June 16, A11. Available at http://www.theglobeandmail.com/news/opinions/article1180738. ece (accessed 28 August 2011).

Hepburn, E. (2009) Introduction: re-conceptualising sub-state mobilisation, Regional \& Federal Studies, 19(4-5), pp. 477-499.

Hepburn, E. (2010) Small worlds in Canada and Europe: a comparison of regional party systems in Quebec, Bavaria and Scotland, Regional \& Federal Studies, 20(4-5), pp. 527-544.

Hooghe, L. (Ed.) (1996) Cohesion Policy and European Integration: Building Multilevel Governance (Oxford: Oxford University Press).

Jeffery, C. (2002) Social and regional interests: ESC and the committee of the regions, in: J. Peterson \& M. Shackleton (Eds) The Institutions of the European Union, pp. 326-346 (Oxford: Oxford University Press).

Keating, M. (1988) State and Regional Nationalism: Territorial Politics and the European State (Brighton: Harvester Wheatsheaf).

Keating, M. (Ed.) (2005) Regions and Regionalism in Europe (Cheltenham: Edward Elgar).

Larned, M. (2011) The newest French department, World Policy Blog, April 14. Available at http://www.worldpolicy.org/blog/2011/04/14/newest-french-department (accessed 28 August 2011).

Levine, S. \& Roberts, N. S. (2005) The constitutional structures and electoral systems of Pacific island states, Commonwealth \& Comparative Politics, 43(3), pp. 276-295.

Loughlin, J. (1996) Representing regions in Europe: the committee of the regions, Regional \& Federal Studies, 6(2), pp. 147-165.

McElroy, J. L. \& Sandborn, K. (2005) The propensity for dependence in small Caribbean and Pacific islands, Bank of Valletta Review (Malta), 31(1), pp. 1-16.

Miodownik, D. \& Cartrite, B. (2006) Demarcating political space: territoriality and the ethno-regional party family, Nationalism \& Ethnic Politics, 12(1), pp. 53-82. 
Palan, R. (1998) Trying to have your cake and eating it: how and why the state system has created offshore, International Studies Quarterly, 42(4), pp. 625-643.

Palan, R. (2003) The Offshore World: Sovereign Markets, Virtual Places and Nomad Millionaires (Ithaca, NY: Cornell University Press).

Peckham, R. S. (2003) The uncertain state of islands: national identity and the discourse of islands in nineteenth-century Britain and Greece, Journal of Historical Geography, 29(4), pp. 419-515.

Royle, S. A. (2001) A Geography of Islands: Small Island Insularity (London: Routledge).

Sidaway, J. D. (2007) Enclave space: a new metageography of development?, Area, 39(3), pp. 331-339.

Srebrnik, H. F. (2004) Small island nations and democratic values, World Development, 32(2), pp. 329-342.

Türsan, H. (1998) Ethnoregionalist parties as ethnic entrepreneurs, in: L. De Winter \& H. Türsan (Eds) Regionalist Parties in Western Europe, pp. 1-16 (London: Routledge). 